\title{
PENGGUNAAN BUAH PLUM, ALPUKAT DAN REMPAH DALAM PENGEMBANGAN CLASSIC VINAIGRETTE DRESSING
}

\section{CLASSIC VINAIGRETTE DRESSING INNOVATION USING PLUM, AVOCADO, AND HERBS}

\author{
Nonot Yuliantoro ${ }^{1)}$ \\ 1) Fakultas Pariwisata - Universitas Pelita Harapan \\ Diterima Tanggal 13 Oktober 2020 Disetujui 30 November 2020
}

\begin{abstract}
Dressing is a complement to serving food, especially salads which have a function to complement the dish to be more perfect to be enjoyed. Many types of dressings for salads are known to be popular in the culinary industry, however, it is a good effort to innovate the existing dressing variants as an alternative choice for food connoisseurs. The purpose of this study was to develop a vinaigrette dressing with fruit and spices as a substitute for salad oil and wine vinegar. The method used was research and product development, the analysis was carried out by descriptive analysis by conducting organoleptic tests on 25 trained panelists at the end of 2018 . The results stated that the use of plums, avocado and spices in the development of vinaigrette dressings in terms of taste, color, texture and aroma. declared fit for consumption so it is hoped that it can be used as an alternative in consuming vegetable salads with a high level of similarity to classic vinaigrette dressings so that they can enrich the existing dressing variants.
\end{abstract}

Keywords: product research and development, organoleptic test, classic vinaigrette, plum.

\begin{abstract}
ABSTRAK
Dressing merupakan pelengkap untuk menghidangkan makanan, khususnya salad yang mempunyai fungsiuntuk melengkapi sajian menjadi lebih sempurna untuk dinikmati. Banyak jenis dressing untuk salad yang dikenal secara populer di industry kuliner namun demikian merupakan upaya yang baik untuk melakukan inovasi terhadap varian dressing yang ada sebagai alternatif pilihan bagi para penikmat makanan. Tujuan penelitian ini adalah untuk melakukan sebuah pengembangan dari vinaigrette dressing dengan ingredient buah-buahan dan rempah sebagai pengganti salad oil dan wine vinegar. Metode yang digunakan adalah penelitian dan pengembangan produk, anlisa dilakukan secara deskriptif analisis dengan melakukan uji organoleptic kepada 25 panelis terlatih pada semester kedua tahun 2018. Has il penelitian menyatakan bahwa penggunaan buah plum, alpukat dan rempah pada pengembangan vinaigrette dressing secara rasa, warna, tekstur dan aroma dinyatakan layak untuk dikonsumsi sehingga diharapkan bisa digunakan sebagai alternatif dalam mengonsumsi salad sayur dengan tingkat kemiripan tinggi dengan classic vinaigrette dressing sehingga bisa memperkaya varian dressing yang ada.
\end{abstract}

Kata Kunci: penelitian dan pengembangan produk, tes organoleptic, classic vinaigrette, buah plum.

\section{Pendahuluan}

\subsection{Latar Belakang}

Pada umumnya komposisi menu makanan yang disajikan untuk dikonsumsi terdiri dari protein, karbohidrat dan serat. Guna memenuhi kebutuhan serat yang cukup bagi tubuh diperlukan asupan sayuran ataupun buah dalam pola makan sehari hari. Menurut Almatsier
(2009), Sayuran dan buah-buahan menjadi pilihan sebagai penyeimbang dalam sebuah menu, karena pada umumnya sayuran dan buah-buahan mengandung banyak vitamin dan serat yang dibutuhkan tubuh dalam proses pencernaan. Industri kuliner, dewasa ini banyak menawarkan ragam pilihan makanan yang menyajikan sayuran dan buah sebagai makanan porsi utama. Menurut Gislen (2010), Salad 
dressing adalah cairan agak kental yang digunakan untuk memberikan rasa pada sayuran segar atau buah-buahan, fungsi dressing pada salad sama halnya fungsi sauce pada makanan yaitu memperkaya rasa dan aroma. Pada dasarnya dressing dapat dibedakan menjadi oil and Vinegar dressing dan emulsified dressing yaitu mencampur beberapa bahan hingga menyatu menjadi satu dressing (Cambray Àlvarez, 2019). Jenis-jenis dressing yang favorit dari kategori oil - viegar dan emulsified dressing antara lain italian dressing, vinaigrette, green godess dressing, french dressing, ranch dressing, blue cheese dressing hingga classic vinaigrette dressing.

\subsection{Identifikasi Masalah}

Banyaknya jenis dressing yang beredar di pasaran ataupun ditawarkan dirumah makan menjadi pijakan untuk dilakukan pengembangan akan produk-produk tersebut, mengingat trend dari pola makan yang terjadi ditengah masyarakat yang terus bergulir menuntut adanya sebuah perubahan dengan berbagai macam alasan. Salah satu kebutuhan akan pengembangan produk dressing adalah dengan banyak munculnya issue tentang gaya hidup, terutama adalah obesitas yang terjadi dikalangan remaja di masayarakat (Khodijah, Lukman and Munigar, 2013), demikian pula kesadaran masyarakat pada umumnya untuk mengonsumsi makanan yang mengandung banyak serat dan baik untuk kesehatan (Kusharto, 2006). Berdasarkan latar belakang tersebut maka dalam penelitian ini dibatasi pada jenis oil and vinaigrette dressing yaitu dressing dengan bahan dasar olive oil dan wine vinegar berkarakteristik cair dan bening.

\subsection{Tujuan dan Manfaat Penelitian}

Tujuan melakukan pengembangan classic vinaigrette dressing adalah untuk menghasilkan produk inovasi dressing (Jung et $a l ., 2011)$ yang berkarakteristik cair dengan cita rasa yang menyerupai classic vinaigrette dressing dengan menggunakan bahan dasar buah plum segar, minyak alpukat dan rempahrempah. Alasan pemilihan classic vinaigrette dressing untuk di kembangkan, mengingat classic vinaigrette adalah dasar dari dressing
(Gisslen, 2010) dan menjadi salah satu dressing yang digemari masyarakat untuk menikmati aneka hidangan salad. Hasil pengembangan atau inovasi diharpakan mampu untuk memberikan alternatif bagi masyarakat untuk menikmati vinaigrette dressing dengan bahan dasar buah-buahan dan rempah yang sangat mudah untuk dibuat sendiri dirumah tanpa menggunakan bahan olive oil maupun wine vinegar.

Tabel 1. Kandungan Gizi Buah Plum

\begin{tabular}{lllr} 
No & Nutrisi & Unit & Value/100gr \\
\hline 1 & Air & gr & 87.23 \\
\hline 2 & Energy & Kcal & 46.00 \\
\hline 3 & Protein & gr & 0.70 \\
\hline 4 & Lemak & gr & 0.28 \\
\hline 5 & Karbohidrat & gr & 11.42 \\
\hline 6 & Fiber & gr & 1.40 \\
\hline 7 & Gula & gr & 9.92 \\
\hline 8 & Kalsium & mg & 6.00 \\
\hline 9 & Besi & gr & 0.17 \\
\hline 10 & Magnesium & $\mathrm{mg}$ & 7.00 \\
\hline 11 & Pospor & $\mathrm{mg}$ & 16.00 \\
\hline 12 & Sodium & $\mathrm{mg}$ & 0 \\
\hline 13 & Zinc & $\mathrm{mg}$ & 0.10 \\
\hline 14 & Vitamin C & $\mathrm{mg}$ & 9.50 \\
\hline 15 & Vitamin B6 & $\mathrm{mg}$ & 0.029 \\
\hline 16 & Vitamin E & $\mathrm{mg}$ & 0.26
\end{tabular}

Sumber: USDA 2016

\section{Metode Penelitian}

Mekanisme penelitian dan pengembangan diawali dengan membuat sebuah perencanaan penelitian yang berisi prosedur atau langkahlangkah penelitian dengan menentukan topik berdasarkan latar belakang yang telah disampaikan, tujuan dari penelitian dan pengembangan produk untuk memberikan alternatif pilihan vinaigrette dressing dengan menggunakan buah plum sebagai bahan utama sehingga memberikan referensi alternatif untuk khalayak umum. Mengingat classic vinaigrette dressing adalah salah satu jenis dressing yang favorit dan banyak digemari dikalangan masyarakat (Kantun, 2013).

Pengembangan produk dilakukan dengan menentukan jenis buah yang mempunyai karakteristik tekstur yang bening dan cair untuk dijadikan bahan pengganti olive oil dan wine 
vinegar, dari berbagai macam uji coba yang dilakukan maka buah plum segar adalah jenis buah yang tepat sebagai bahan utama dan ditambahakan dengan minyak alpukat dan rempah-rempah yang digunakan untuk membuat inovasi dari classic vinaigrette dressing yang diharapkan mempunyai kemiripan rasa, tekstur dan aroma dengan vinaigrette dressing pada umumnya.

Uji coba terbatas dilakukan untuk mendapatkan formula yang tepat untuk menghasilkan kualitas produk yang akan dicapai, dengan menentukan tingkat kematangan buah plum yang tepat, dan takaran rempah-rempah yang digunakan untuk menghasilkan dressing yang menyeruapai dengan classic vinaigrette dressing pada umumnya (Astuti, Suriani and Damiati, 2018).

Penyempurnaan dari uji coba terbatas atas pengembangan classic vinaigrette dressing dengan menambahkan buah tomat agar supaya menghasilkan warna, aroma dan rasa dengan tingkat kemiripan yang tinggi dengan vinaigrette dressing pada umumnya. Setelah didapatkan hasil produk pengembangan dengan tingkat kemiripan yang tinggi dengan produk yang sebenarnya maka dilakukan penganalisaan data dengan uji sensorik yaitu uji organoleptik untuk dianalisa dengan uji hedonik dan uji mutu hedonic yang melibatkan para panelis terlatih dibidang kuliner.

\subsection{Bahan dan alat yang digunakan.}

Dalam penelitian pengembangan classic vinaigrette dressing menggunakan bahanbahan berupa buah plum impor segar yang berkualitas baik dan sudah matang ditambah dengan minyak alpukat dari buah alpukat mentega dan rempah-rempah untuk menghasilkan tekstur aroma, warna dan rasa yang menyerupai produk orisinilnya.

Alat yang digunakan antara lain meja kerja, blender, panci alumunium diameter $25 \mathrm{~cm}$, mangkuk kecil, pisau dapur, saringan, balloon whisk, sendok makan, talenan, sauce boat dan ramekin.

Dalam penelitian ini merupakan penelitian pengembangan yaitu sebuah metode penelitian dengan melakukan serangkaian proses atau langkah-langkah untuk mengembangkan suatu produk baru atau menyempurnakan produk yang telah ada dengan melakukan pengendalian terhadap variable di luar objek yang dieksperimenkan, (Council, 1977).

Variabel penelitian adalah segala suatu yang ditetapkan oleh peneliti untuk dipelajari sehingga diperoleh informasi tentang hal tersebut, kemudian ditarik kesimpulan, hal ini sesuai dengan yang di tulis oleh Sugiono (2009). Dalam penelitian ini memakai 1 variabel yaitu variabel $\mathrm{X}$ adalah buah plum. Populasi dari penelitian ini adalah dressing yang lazim untuk disajikan pada sajian salad buah atau sayur, sedangkan sampel yang dipilih adalah classic vinaigrette dressing untuk dikembangkan tanpa menggunakan wine vinegar digantikan dengan buah plum.

Menurut Sugiono (2009), One Shot Case Study adalah merupakan desain penelitian yang terdiri dari sebuah kelompok yang diberi perlakuan yang kemudian dilakukan observasi terhadap fenomena hasil yang terjadi. Dalam penelitian ini dilakukan uji organoleptik yaitu uji sensori dengan mekanisme uji hedonik dan uji mutu hedonik yang dilakukan oleh 25 orang panelis terlatih dibidang kuliner. Para panelis diminta untuk mencoba dressing yang sudah dibuat kemudian memberikan nilai pada tabel penilaian yang diberikan.

Menurut Valliant, Dorfman dan Royall (2000) mengatakan bahwa penentuan populasi dan sampel penelitian menjadi hal yang krusial karena hasil penelitian akan disimpulkan secara menyeluruh. Ketepatan dan keakuratan dalam penentuan populasi dan sampel penelitian akan memengaruhi kualitas hasil penelitian.

Sekaran dan Bougie (2009) menyatakan bahwa sampling process merupakan proses pemilihan jumlah yang tepat dari unsur-unsur yang tepat dari populasi, sehingga studi tentang sampel dan pemahaman tentang sifat atau karakteristiknya memungkinkan untuk mengeneralisasikan sifat atau karakteristik tersebut.

Jenis oil vinegar dressing pada umumnya menggunakan bahan dasar olive oil dan wine 
vinegar. Dressing dengan kandungan wine vinegar menyebabkan banyak individu merasa terlalu asam karena merupakan hasil fermentasi dari buah anggur. Oleh sebab itu, dilakukan penelitian dan pengembangan salah satu jenis oil and vinegar yaitu classic vinaigrette dressing, dibuat tanpa menggunakan bahan yang mengandung wine vinegar dan diganti bahan dengan menggunakan bahan utama buah plum segar dengan tingkat kematangan buah tertentu.

\subsection{Teknik Pengumpulan Data}

Sekaran dan Bougie (2019) juga mengatakan bahwa data primer adalah kumpulan data yang didapatkan dari sumber asli yang sesuai dengan tujuan penelitiannya. Penelitian ini menggunakan data primer dari hasil kuisioner tentang Penggunaan buah plum dalam pembuatan inovasi classic vinaigrette dressing sebagai pengganti penggunaan oil dan vinegar dengan empat aspek penilaian yaitu aspek rasa, warna, tekstur dan aroma. Panelis dapat menilai setiap aspek bantuan skala dan memberi tanggapan pribadinya pada kolom yang sudah disediakan (Saragih, 2014).

Menurut Stone, Bleibaum, dan Thomas (2012), uji organoleptik atau uji sensori adalah sebuah penelitian yang dilakukan untuk menganalisa aspek rasa, warna, testur dan aroma terhadap pengujian sebuah produk yang didasarkan pada proses penginderaan. Maka dari itu pengujian organoleptik mempunyai peranan penting dalam penerapan kualitas suatu produk. Penelitian dan pengembangan dilakukan dengan penyebaran uji sensorik hedonik dan mutu hedonik pada inovasi dressing menggunakan buah plum segar dengan tingkat kematangan tertentu sebagai pengganti wine vinegar. Uji Hedonik dikutip di dalam buku karangan Setyaningsih, Dwi, Apriyantono dan Sari (2010) Uji hedonik atau kesukaan adalah untuk mengetahui respon panelis terhadap sifat mutu yang umum. Uji hedonik memberikan pernyataan kesan tentang baik atau buruknya suatu produk. Uji ini dilakukan untuk mengetahui tingkat kesukaan produk yang satu dengan produk yang lain secara langsung. Uji ini dapat diaplikasikan saat pengembangan produk atau pembanding produk.

Menurut Sarastani (2012). Uji hedonik dilakukan dengan cara panelis diminta tanggapan pribadinya tentang kesukaan atau ketidaksukaannya terhadap komoditi yang dinilai, bahkan tanggapan dengan tingkatan kesukaan atau tingkatan ketidak sukaannya dalam bentuk skala hedonik. Sedangkan untuk Uji mutu hedonik merupakan kesan mutu hedonik lebih spesifik, yaitu tidak sekedar suka atau tidak suka tetapi bersifat kesan spesifik dari sifat khas produknya . Maka dari itu dilakukan uji mutu hedonik untuk mengetahui kualitas produk penggunaan plum sebagai bahan classic vinaigrette dressing yang telahdi teliti. Skala yang digunakan dalam penelitian ini adalah adaptasi dari lima skal likert yang berturut-turut dari skala 1 yang artinya tidak baik atau tidak suka, skala 2 yang diartikan agak baik atau agak suka, skala 3 artinya agak baik atau agak suka, skala 4 srtinya baik atau suka dan skala 5 yang berarti sangat baik atau sangat suka (Boone and Boone, 2012). Secara rinci berikut adalah table untuk skala hedonic dan skala mutu hedonik yang digunakan dalam penelitian ini.

\section{Tabel 2 Skala Hedonik Dengan 5 Skala Numerik}

Skala Hedonik - Skala Numerik

\begin{tabular}{ll}
\hline Sangat Suka & 5 \\
\hline Suka & 4 \\
\hline Agak Suka & 3 \\
\hline Agak Tidak Suka & 2 \\
\hline Tidak Suka & 1
\end{tabular}

Sumber: Saludung dan Yahya (2018)

Dengan skala tabel di atas maka dapat membantu untuk mengetahui tingkat kesukaan responden terhadap penggunaan buah plum segar dengan tingkat kematangan tertentu sebagai bahan pembuatan inovasi dari classic vinaigrette dressing. Skala hedonik dapat digunakan sesuai kebutuhan dari peneliti dimulai dari sangat suka, suka, agak suka, agak tidak suka, tidak suka. Dengan adanya skala ini 
secara tidak langsung dapat mengetahui perbedaan antar variabel. Kesukaan seseorang terhadap penggunaan buah plum segar dengan tingkat kematangan tertentu sebagai bahan pembuatan pengembangan classic vinaigrette dressing penting dalam penelitian ini karena hal tersebut dapat memberikan penilaian dan penentuan dalam hasil penelitian. Salah satu dari tujuan pengembangan ini adalah untuk memastikan bahwa hasil pengembangan dressing yang dilakukan disukai oleh panelis yang akan menjadi rekomendasi bagi semua yang akan mengonsumsi dressing hasil pengembangan ini.

\section{Tabel 3 Skala Mutu Hedonik Dengan 5 Skala Numerik}

\begin{tabular}{|c|c|}
\hline Skala Mutu Hedonik & - SkalaNumerik \\
\hline Sangat Baik & 5 \\
\hline Baik & 4 \\
\hline Agak Baik & 3 \\
\hline Agak Tidak Baik & 2 \\
\hline Tidak Baik & 1 \\
\hline
\end{tabular}

\subsection{Teknik Analisis Data}

Dalam penelitian dan pengembangan ini, teknik analisis data dilakukan dengan cara menggunakan analisis sensori (Stone, Bleibaum and Thomas, 2012) yaitu mengidentifikasi dan mendiskripsikan aspek rasa, warna, aroma dan tekstur dari buah plum segar dengan tingkat kematangan tertentu sebagai bahan substitusi bahan mengandung wine vinegar sedangakan rata-rata hitung dalam pengolahan data dari uji hedonik dan mutu hedonik dengan cara sebagai berikut: Total nilai per indikator di jumlahkan : total panelis sehingga peneliti akan mendapatkan hasil nilai rata-rata per aspek seperti rasa, warna, aroma, tekstur serta rata-rata secara keseluruhan terhadap penggunaan buah plum pada classic vinaigrette dressing.

Perode penelitian ini berlangsung mulai dari Agustus - Desember 2018. Sedangkan pengambilan data uji sensori hedonik dan mutu hedonik dilakukan pada pada minggu ke dua di bulan oktaber 2018. Kedalaman ekperimen pada penelitian ini sebatas untuk mengetahui bagaimana jenis buah yang telah dipilih yaitu buah plum segar dengan tingkat kematangan tertentu dapat menggantikan rasa, aroma, warna, dan tekstur dari kandungan wine vinegar dalam pembuatan inovasi classic vinaigrette dressing.

\section{Hasil dan Pembahasan}

Dibawah ini merupakan tabel olahan data dari hasil pengambilan data yang dilakukan oleh panelis dengan teknik uji hedonik dan mutu hedonik pada classic vinaigrette dressing menggunakan buah plum, alpukat dan rempahrempah.

Tabel 4. Uji Hedonik Classic Vinaigrette dressing Menggunakan Bahan Buah Plum, alpukat dan rempah.

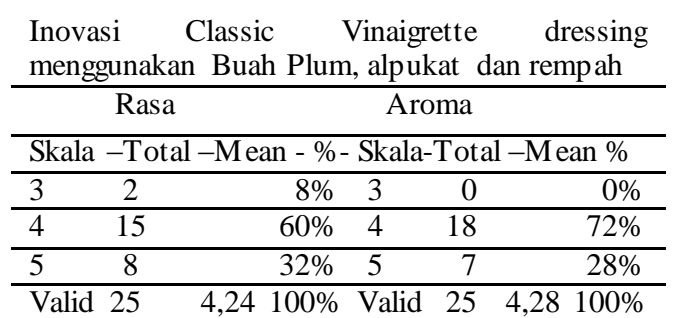

Sumber : Olahan Data

Berdasarkan data diatas, dapat dideskripsikan bahwa aspek rasa dari sampel dressing berbahan dasar buah plum segar dengan tingkat kematangan tertentu, menghasilkan rasa yang dapat diterima melalui uji sensori dengan tingkat kesukaan pada numerik 4 yaitu suka sebesar $60 \%$ dan rasa dressing dengan tingkat kesukaan sangat suka yaitu skal 5 sebanyak $32 \%$ dan sisanya adalah $8 \%$ dengan tingkatan agak suka. Dari pemaparan tersebut dapat dikatakan bahwa aspek rasa dari Penggunaan buah plum segar sebagai bahan dasar inovasi classic vinaigrette dressing sebagai pengganti wine vinegar dapat diterima dengan baik karena menyerupai rasa dressing yang diinovasikan. Sedangkan untuk aroma dari inovasi classic vinaigrette dressing sebanyak $52 \%$ dari responden menyatakan suka, $44 \%$ memberikan penilaian sangat suka dan sebesar $4 \%$ agak suka. Tingkat kesukaan yang tinggi pada aroma dressing berbahan dasar buah plum segar dengan tingkat kematngan tertentu ditambahkan dengan rempah-rempah dapat diartikan bahwa aroma dari dressing tersebut adalah dapat diterima dengan baik karena 
mempunyai aroma yang segar menyerupai dengan aroma dari dressing yang sebenarnya.

Tabel 5. Uji Hedonik Classic Vinaigrette dressing Menggunakan Bahan Buah Plum, alpukat dan rempah.

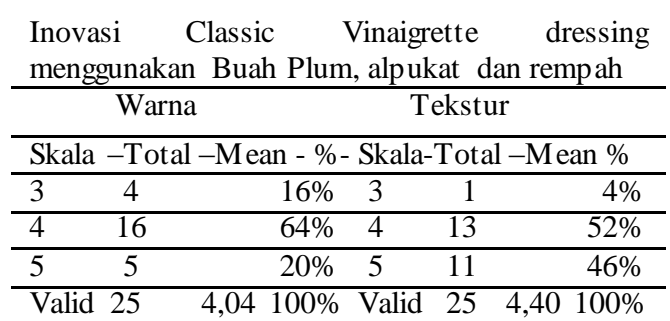

Sumber : Olahan Data

Berdasarkan data diatas, dari aspek warna inovasi Classic vinaigrette dressing menggunakan bahan dasar buah plum segar dengan tingkat kematngan tertentu ditambah dengan rempah-rempah ini mendapatkan penilaian sebesar $28 \%$ sangat suka dengan warnanya, dan 68\% suka dengan warna dressing tersebut. Dapat diartikan aspek warna sangat bisa diterima dengan rata-rata tingkat kesukaan 4,04 hal ini dikarenakan warna dressing dari buah plum segar dengan tingkat kematangan tertentu ditambahkan dengan rempah-rempah menyerupai warna dari classic vinaigrette dressing yang sebenarnya. Untuk aspek tekstur dari dressing berbahan dasar buah plum segar ini juga mendapatkan respon bagus dari panelis dengan $6 \%$ sangat suka dan $52 \%$ suka dengan tekstur dari dressing tersebut. Dari data tersebut diatas dapat dikatakan bahwa tekstur inovasi dressing ini menghasilkan inovasi produk dressing yang menyerupai tekstur dari classic vinaigrette dressing .

Tabel 6. Uji Mutu Hedonik Classic Vinaigrette dressing Menggunakan Bahan Buah Plum, alpukat dan rempah.

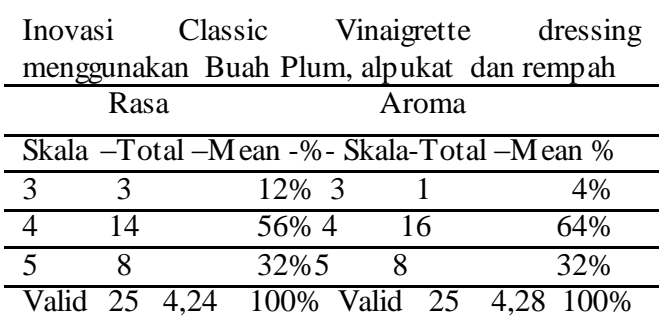

Sumber : Olahan Data

Tabel diatas menjelaskan bahwa rasa dari inovasi dressing berbahan plum mempunyai mutu yang baik dengan pencapaian $56 \%$, penilaian sangat baik sebesar $32 \%$ dan agak baik sebesar $8 \%$. Secara rata-rata kualitas atau mutu dari rasa dressing berbahan buah plum ini adalah 4,24 yang artinya bermutu bagus. Sedangkan mutu dari aroma dressing berbahan buah plum ini adalah $64 \%$ menyatakan bermutu baik, $32 \%$ menyatakan bermutu sangat baik dan 4\% menyatakan mutu agak baik. Dengan pencapaian mean 4,28 dapat diartikan bahwa rasa inovasi dressing dengan bahan utama buah plum segar ini mempunyai kemiripan yang tinggi dengan dressing yang sebenarnya dan memiliki aroma vinaigrette yang menyerupai dressing aslinya meskipun terbuat dari buah plum sebagai pengganti wine vinegar. Pencapaian nilai mean 4,28 sebagai indicator bahwa rasa dressing hasil pengembangan mempunyai kualitas atau mutu diatas rata-rata bahkan mencapai nilai mean mendekati 5 yaitu sangat bagus kualitasnya.

Tabel 7. Uji Mutu Hedonik Classic Vinaigrette dressing Menggunakan Bahan Buah Plum, alpukat dan rempah.

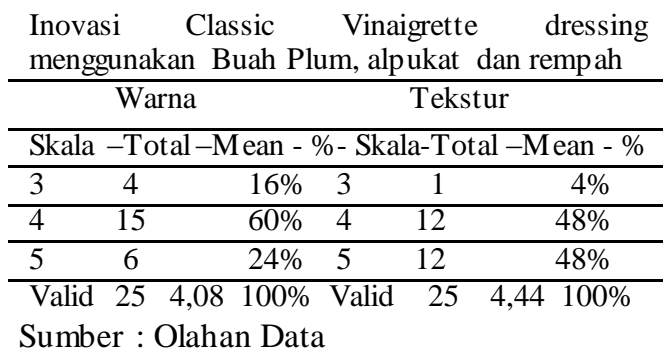

Berdasarkan data diatas, dapat dikatakan bahwa warna dressing berbahan buah plum mempunyai kualitas atau mutu warna yang baik dengan pencapaian mean 4,08 yang artinya kemiripan warna yang tinggi dengan dressing yang sebenarnya. Selain itu untuk tekstur dari dressing tersebut mempunyai mutu yang bagus dengan kekentalan dan tekstur yang sesuai dengan classic dressing vinaigrette sehingga secara data mencapai mean 4,08 dengan rincian $24 \%$ penilaian dengan skala 5 yang berarti sangat bermutu dan $60 \%$ slala 4 yang artinya bermutu. Dari paparan tersebut dapat dikatakan bahwa warna inovasi dressing ini mempunyai kemiripan yang tinggi dengan dressing sebenarnya dan memiliki tektur dengan tingkat kekentalan dressing berbahan buah plum yang 
berkualitas bagus. Pencapaian nilai mean diatas 4 berarti pada skala antara mea 4 dan mean 5 sangat bagus, artinya kualitas warna dari dressing hasil pengembangan mempunyai kualitas diatas rata-rata atau cenderung mempunyai kualitas yang bagus karena warna yang dihasilkan menyerupai warna asli dari dressing yang dikembangkan.

\section{Simpulan}

Penelitian dan pengembangan ini bertujuan untuk menginovasikan Classic vinaigrette dressing yang merupakan jenis oil vinegar dressing dan banyak digemari masyarakat, tanpa menggunakan wine vinegar dan digantikan dengan buah plum segar dengan tingkat kematangan tertentu untuk menghasilkan tingkat kekentalan dan kesegaran yang sesuai dengan tektur yang sebenarnya.

Pemilihan buah plum segar sebagai bahan utama karena jenis buah plum yang masak mempunyai rasa manis dengan karakteristik tekstur yang bening (Singh and Khan, 2010) apabila dihaluskan dan disaring, menghasilkan rasa yang mirip dengan classic vinaigrette dressing apabila sudah dicampur dengan minyak alpukat dan rempah-rempah dan mempunyai kandungan nutrisi yang memadai untuk kebutuhan tubuh manusia.

Dari hasil uji organoleptik yang dilaksanakan oleh para panelis terlatih dengan melakukan uji hedonik dan mutu hedonik didapatkan hasil bahwa penggunaan buah plum segar dengan tingkat kematangan tertentu sebagai bahan pengganti wine vinegar, dalam pembuatan classic vinaigrette dressing dari aspek rasa, aroma, warna dan tekstur yang dapat diterima dan disukai oleh para panelis sehingga inovasi atau pengembangan classic vinaigrette dressing menghasilkan dressing yang bermutu atau berkualitas baik.

Dapat dikatakan bahwa hasil penelitian dan pengembangan terhadap classic vinaigrette dressing dengan menggunakan bahan utama buah plum menghasilkan dressing yang sangat layak untuk dikonsumsi karena menghasilkan rasa, aroma, warna, dan tektur dengan tingkat kemiripan yang tinggi dengan classic vinaigrette dressing yang sebenarnya, sehingga bisa dijadikan sebagai alternatif dressing bagi masyarakat penggemar classic vinaigrette dressing yang tidak bisa mengonsumsi wine vinegar karena alasan tertentu.

\section{Keterbatasan Penelitian}

Karena keterbatasan waktu dalam penelitian maka dalam penelitian ini hanya fokus pada pengembangan untuk jenis vinaigrette dressing dengan menggunakan buah-buahan dan rempah yang bukan produk lokal Indonesia. Diharapakan penelitian selanjutnya bisa memaksimalkan buah-buahan lokal untuk dijadikan bahan pengembangan produk makan yang diteliti karena dengan penggunaan bahanbahan local akan memudahkan dalam pengadaannya di pasar atau swalayan.

Ucapan Terima kasih

Ucapkan terima kasih yang tak terhingga kepada Lembaga Penelitian dan Pengabdian kepada masyarakat Universitas Pelita Harapan yang telah memfasilitasi pelaksanaan penelitian ini dan tentunya semua pihak yang telah membantu dalam proses penulisan artikel ini, kiranya artikel ini bisa bermakfaat sebagai refensi bagi siapapun yang membacanya.

\section{Daftar Pustaka}

Almatsier, S. (2009) 'Prinsip Dasar Ilmu Gizi. pdf'. VII). Jakarta: PT Gramedia Pustaka Utama.

Astuti, N. P. E. W., Suriani, N. M. and Damiati, M. K. (2018) 'Uji Kualitas Tepung Kara Kratok', Jurnal BOSAPARIS: Pendidikan Kesejahteraan Keluarga, $8(2)$.

Boone, H. N. and Boone, D. A. (2012) 'Analyzing likert data', Journal of extension, 50(2), pp. 1-5.

Cambray Àlvarez, C. (2019) 'Development of three salad dressings: a vinaigrette, a sweet salad dressing and a vegan salad dressing'.

Council, N. R. (1977) World food and nutrition study. The potential contributions of 
research. National Academy of Sciences.

Dwi, S., Anton, A. and Maya, P. S. (2010) 'Analisis sensori untuk industri pangan dan agro'. Bogor: IPB Press.

Gisslen, W. (2010) Professional cooking, college version. John Wiley \& Sons.

Jung, H.-A. et al. (2011) 'Study Development of Salad Dressing with Added Sea Tangle (\$ Laminaria \$ japonica \$)', The Korean Journal of Food And Nutrition, 24(4), pp. 520-527.

Kantun, S. (2013) 'Hakikat dan Prosedur Penelitian Pengembangan'.

Khodijah, D., Lukman, E. and Munigar, M. (2013) 'Obesitas dengan kualitas hidup remaja', Jurnal Health Quality, 3(2), pp. 69-140.

Kusharto, C. M. (2006) 'Serat makanan dan perannya bagi kesehatan', Jurnal gizi dan pangan, 1(2), pp. 45-54.

Saludung, J. and Yahya, M. (2018) 'Pemanfaatan buah lontar untuk pengembangan kewirausahaan berbasis ecopreneurship melalui home industry pada ibu-ibu PKK di Makassar', in Seminar Nasional Pengabdian Kepada Masyarakat.
Saragih, R. (2014) 'Uji kesukaan panelis pada teh daun torbangun (Coleus amboinicus)', E-Journal Widya Kesehatan dan Lingkungan, 1(1).

Sarastani, D. (2012) 'Penuntun praktikum analisis organoleptik', Bogor: Program Diploma Institut Pertanian Bogor.

Singh, Z. and Khan, A. S. (2010) 'Physiology of plum fruit ripening'.

Stone, H., Bleibaum, R. N. and Thomas, H. A. (2012) Sensory evaluation practices. Academic press.

Sugiyono, M. P. P. and Kuantitatif, P. (2009) 'Kualitatif, dan R\&D, Bandung: Alfabeta', Cet. VII.

Umar, S. and Bougie, R. (2009) 'Research methods for business: A skill building approach'. John Wiley \& Sons, Limited. Academic Internet Publishers Incorporated.

Valliant, R., Dorfman, A. H. and Royall, R. M. (2000) Finite population sampling and inference: a prediction approach. John Wiley New York.

https $/ /$ www.ams.usda.gov/gradesstan/mangogrades-and-standards 